\title{
PKM Peningkatan Pengetahuan Keluarga Penerima Manfaat Program Keluarga Harapan tentang Stunting di Desa Sidodadi Kecamatan Paiton Kabupaten Probolinggo
}

\author{
M Noer Fadli Hidayat ${ }^{1 *}$, Handono Fatkhur Rahman², \\ Mohammad Alfian Faisol Mustaqim³ ${ }^{3}$, Fauzan Abdul Latif ${ }^{4}$, \\ Dwiki Qutsi Ali Multazam ${ }^{5}$ Anando Setyo Adiwirawan ${ }^{6}$ \\ Universitas Nurul Jadid Probolinggo $1,2,3,4,5,6,7,8,9,10,11$ \\ \{fadli@unuja.ac.id ${ }^{1}$, handono@unuja.ac.id $\left.{ }^{2}\right\}$
}

\begin{tabular}{ll}
\hline Submission: 17/10/2021 & Received: 31/12/2021 Published: 31/12/2021 \\
\hline Katakunci: & Abstrak. Di Indonesia terdapat 1,2 juta bayi lahir dalam keadaan \\
Stunting, PKH, & stunting. Untuk itulah pada awal tahun 2021, Pemerintah \\
Probolinggo & Indonesia menargetkan angka Stunting turun menjadi $14 \%$ di \\
& tahun 2024. Kabupaten Probolinggo kasus stunting di tahun 2021 \\
& dari jumlah balita sebanyak 79,356 anak penderita stunting \\
& mencapai 12,769 anak atau 16,01\%. Jumlah ini menjadikan \\
& Kabupaten Probolinggo berada di posisi 5 daerah terbanyak \\
& penderita stunting Provinsi Jawa Timur. Dari jumlah sebaran \\
& penderita sunting Kabupaten Probolinggo, di Kecamatan Paiton \\
& jumlah penderita stunting tahun 2021 tercatat sebanyak 745 anak \\
& atau 14\% dari jumlah balita 5,276 anak. Dari 20 desa yang ada di \\
& Kecamatan Paiton, desa terbanyak penderita stunting adalah Desa \\
& Sidodadi dengan jumlah 145 anak dari 390 balita atau sebanyak \\
& 37\%. Tujuan PKM ini adalah memberikan penyuluhan dan \\
& pendampingan untuk meningkatkan wawasan dan kesadaran \\
& masyarakat Desa Sidodadi Kecamatan Paiton Kabupaten \\
& Probolinggo dalam mencegah dan mencegah penderita stunting. \\
& Hasil yang dicapai dalam PKM ini adalah telah meningkatnya \\
& pengetahuan peserta tentang penanganan dan pencegahan \\
& stunting. Dimana dari hasil pre-test dengan tingkat pengetahuan \\
& baik sekali mencapai 53\%, tingkat pengetahuan baik 27\% dan \\
& tingkat pengetahuan kurang menurun menjadi 20\%. \\
\hline
\end{tabular}

\section{Pendahuluan}

Istilah stunting pada hakikatnya merupakan fenomena kekurangan gizi pada bayi di 1000 hari dalam kehidupan pertamanya dengan berlangsung lama (Bappenas, 2018). Akibat dari kekurangan gizi ini, maka bayi mengalami kendala pada perkembangan otak dan pertumbuhannya (Khadijah, 2016). Bayi yang mengalami stunting cenderung tumbuh lebih pendek dari standar tinggi balita pada umumnya. Artinya, bayi yang mengalami stunting pasti bertubuh pendek, akan tetapi yang bertubuh pendek belum tentu mengalami 
stunting. Selain itu, fenomena stunting pada bayi bisa juga disebabkan karena faktor kehamilan, atau ibu hamil yang menghasilkan bayi stunting (Sartono, 2014).

Menurut dr. Hasto, tingginya angka stunting di Indonesia disebabkan karena ada banyak bayi yang lahir secara normal akan tetapi tumbuh dan berkembang kekurangan asupan gizi, sehingga menjadi stunting. Problem stunting sebenarnya bukan hanya problem kehamilan tapi juga pemberian asupan gizi yang kurang memadai pada bayi, sehingga berdampak buruk terhadap pertumbuhan anak, yang selanjutnya disebut stunting itu (Kemenkes RI, 2018).

Beberapa ahli menyebutkan penyebab terjadinya stunting yang paling banyak berpengaruh ialah; pendapatan keluarga, pemberian ASI eksklusif, besar keluarga, pendidikan ayah balita, pekerjaan ayah balita, pengetahuan gizi ibu balita, ketahanan pangan keluarga, pendidikan ibu balita, tingkat konsumsi karbohidrat balita, ketepatan pemberian MP-ASI, tingkat konsumsi lemak balita, riwayat penyakit infeksi balita, sosial budaya, tingkat konsumsi protein balita, pekerjaan ibu balita, perilaku kadarzi, tingkat konsumsi energi balita, dan kelengkapan imunisasi balita (Aryu, 2020).

Banyak para ahli mengatakan bahwa tingginya angka penyitas stunting di Indonesia disebabkan beberapa faktor yang salah satunya karena kekurangan gizi pada bayi (Ramayulis, 2018). Menurut dr Hasto Wardoyo, diantara 5 juta kelahiran bayi setiap tahun, setidaknya terdapat 1,2 juta bayi lahir dalam keadaan stunting. Untuk itulah pada awal tahun 2021, Pemerintah Indonesia menargetkan angka Stunting turun menjadi $14 \%$ di tahun 2024. Presiden Joko Widodo menunjuk Kepala BKKBN, Dr. (HC) dr. Hasto Wardoyo, Sp.OG. (K) menjadi Ketua Pelaksana Percepatan Penurunan Stunting.

Berdasarkan data yang dirilis kementerian Kesehatan pada tahun 2021 ini, bayi lahir saja sudah $23 \%$ prevalensi stunting. Banyak dari mereka yang lahir normal, tapi pada perkembangannya mengalami stunting, sehingga mencapai 27,6\%. Dengan demikian, angka 23\% itu muncul dari proses kelahiran yang sudah tidak sesuai standar. Selain itu, sebanyak $11,7 \%$ bayi yang mengalami stunting karena terlahir dengan gizi yang kurang atau buruk seperti panjang tubuh bayi yang mencapai 48 sentimeter dan berat badannya tidak mencapai 2,5 kilogram. 
Menurut data Ditjen Bina Pembangunan Daerah Kementerian Dalam Negeri di https://aksi.bangda.kemendagri.go.id/emonev/DashPrev disebutkan bahwa Kabupaten Probolinggo kasus stunting di tahun 2021 dari jumlah balita sebanyak 79,356 anak penderita stunting mencapai 12,769 anak atau 16,01\%. Jumlah ini menjadikan Kabupaten Probolinggo berada di posisi 5 daerah terbanyak penderita stunting Provinsi Jawa Timur. Dari jumlah sebaran penderita sunting Kabupaten Probolinggo, di Kecamatan Paiton jumlah penderita stunting tahun 2021 tercatat sebanyak 745 anak atau 14\% dari jumlah balita 5,276 anak. Dari 20 desa yang ada di Kecamatan Paiton, desa terbanyak penderita stunting adalah Desa Sidodadi dengan jumlah 145 anak dari 390 balita atau sebanyak $37 \%$.

Tabel 1. Sebaran penderita stunting Kecamatan Paiton Tahun 2021

\begin{tabular}{|c|c|c|c|c|c|c|c|}
\hline \multirow[b]{2}{*}{ No } & \multirow[b]{2}{*}{ ID BPS } & \multirow[b]{2}{*}{ ID Dagri } & \multirow[b]{2}{*}{ Nama Desa } & \multirow[b]{2}{*}{$\begin{array}{c}\text { Jumlah } \\
\text { Balita }\end{array}$} & \multicolumn{2}{|c|}{ Stunting } & \multirow{2}{*}{$\begin{array}{c}\text { Prevalensi } \\
\%\end{array}$} \\
\hline & & & & & Pendek & $\begin{array}{l}\text { Sangat } \\
\text { Pendek }\end{array}$ & \\
\hline 1 & 3513130001 & 3513122003 & Jabung Wetan & 258 & 11 & 3 & 05.04 \\
\hline 2 & 3513130002 & 3513122004 & Kalikajar Kulon & 240 & 34 & 8 & 17.05 \\
\hline 3 & 3513130003 & 3513122005 & Kalikajar Wetan & 211 & 26 & 10 & 17.01 \\
\hline 4 & 3513130004 & 3513122007 & Alastengah & 196 & 20 & 3 & 11.07 \\
\hline 5 & 3513130005 & 3513122006 & Pandean & 317 & 11 & 5 & 05.00 \\
\hline 6 & 3513130006 & 3513122013 & Petunjungan & 268 & 4 & 0 & 01.05 \\
\hline 7 & 3513130007 & 3513122014 & Taman & 163 & 6 & 2 & 04.09 \\
\hline 8 & 3513130008 & 3513122012 & Plampang & 162 & 11 & 7 & 11.01 \\
\hline 9 & 3513130009 & 3513122008 & Sidodadi & 390 & 86 & 59 & 37.02 \\
\hline 10 & 3513130010 & 3513122002 & Jabung Candi & 161 & 16 & 8 & 14.09 \\
\hline 11 & 3513130011 & 3513122001 & Jabungsisir & 304 & 50 & 1 & 16.08 \\
\hline 12 & 3513130012 & 3513122009 & Randumerak & 167 & 34 & 2 & 21.06 \\
\hline 13 & 3513130013 & 3513122010 & Randutatah & 109 & 9 & 2 & 10.01 \\
\hline 14 & 3513130014 & 3513122011 & Karanganyar & 450 & 56 & 16 & 16.00 \\
\hline 15 & 3513130015 & 3513122017 & Pondok Kelor & 352 & 37 & 2 & 11.01 \\
\hline 16 & 3513130016 & 3513122016 & Sukodadi & 275 & 31 & 9 & 14.05 \\
\hline 17 & 3513130017 & 3513122015 & Paiton & 156 & 20 & 10 & 19.02 \\
\hline 18 & 3513130018 & 3513122018 & Sumberanyar & 567 & 64 & 16 & 14.01 \\
\hline 19 & 3513130019 & 3513122019 & Sumberejo & 332 & 19 & 1 & 06.00 \\
\hline 20 & 3513130020 & 3513122020 & Bhinar & 198 & 27 & 9 & 18.02 \\
\hline
\end{tabular}

Berdasarkan uraian di atas, perlu ada upaya edukasi kepada masyarakat khususnya kepada kalangan remaja, ibu hamil atau yang memiliki balita, masyarakat dengan pendidikan rendah serta masyarakat ekonomi lemah. Dengan adanya kegiatan pengabdian masyarakat ini diharapkan dapat meningkatkan wawasan dan kesadaran masyarakat Desa Sidodadi 
Kecamatan Paiton Kabupaten Probolinggo dalam mencegah dan mencegah penderita stunting.

\section{Metode}

Untuk memecahkan masalah yang sudah diidentifikasi dan dirumuskan tersebut diatas, maka alternatif pemecahan masalah metode pelaksanaan dalam program pengabdian kepada masyarakat melalui pemberian penyuluhan dan pendampingan praktik pencegahan dan penanganan stunting kepada Keluarga Penerima Manfaat (KPM) Program Keluarga Harapan (PKH) Desa Sidodadi Kecamatan Paiton yang masuk dalam kategori ibu hamil dan balita. Secara garis besar kegiatan pengabdian kepada masyarakat ini dibagi ke dalam 5 (lima) tahap yaitu; (1) Menjalin kerjasama dengan pendamping Program Keluarga Harapan (PKH) Kecamatan Paiton Kabupaten Probolinggo, (2) Menentukan peserta dan penyusunan jadwal kegiatan, (3) Merumuskan materi penyuluhan dan model pendampingan, (4) Pengukuran hasil dan evaluasi kegiatan penyuluhan dan pendampingan, (5) Penyusunan laporan dan publikasi.

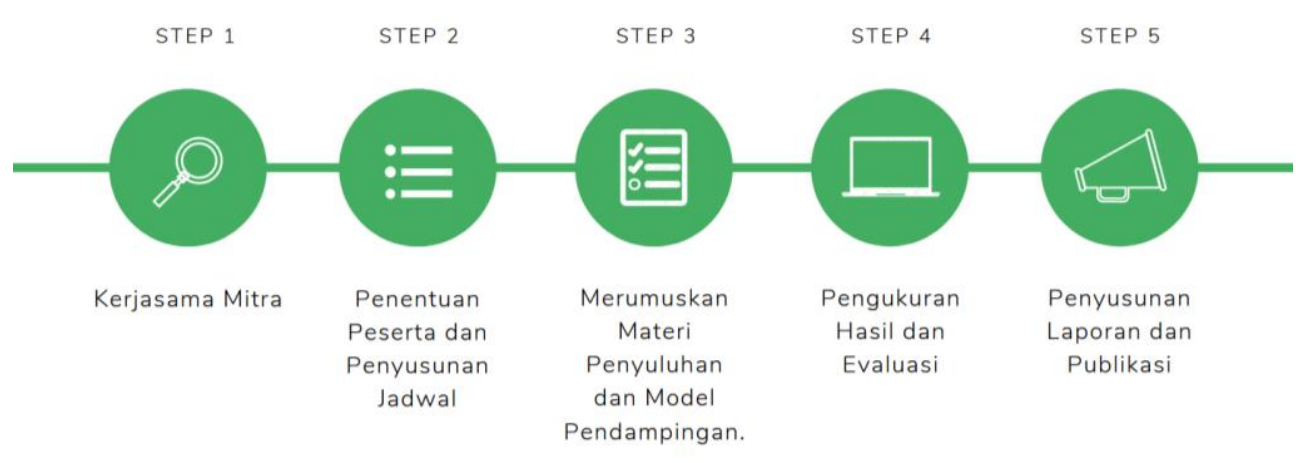

Gambar 1. Tahapan Kegiatan PKM

Masing-masing tahapan kegiatan pengabdian kepada masyarakat ini secara rinci diuraikan sebagai berikut:

1. Kegiatan ini diawal dengan menjalin kerjasama dengan mitra yang relevan agar tujuan kegiatan ini dapat terwujud. Selain dilibatkan dalam proses pelaksanaan penyuluhan dan pendampingan, mitra 
kerjasama juga dilibatkan dalam mengkaji permasalahan, pemetaan sasaran peserta, penyusunan materi dan proses evaluasi.

2. Agar pelaksanaan kegiatan ini berjalan dengan baik dan tepat sasaran, langkah selanjutnya adalah menentukan peserta berdasarkan kategori dan sebaran tempat tinggal KPM PKH dengan mempertimbangkan ketersediaan tempat, waktu, kondusifitas penyuluhan dan pendampingan serta keberlanjutan program.

3. Untuk mencapai kompetensi yang ingin dicapai dalam kegiatan ini, tahap selanjutnya adalah menyusun materi penyuluhan dan menentukan model pendampingan dalam mengimplementasikan materi-materi yang telah dilakukan dalam proses penyuluhan.

4. Melakukan evaluasi terhadap semua target kegiatan PKM.

5. Tahap terakhir dalam kegiatan ini adalah penyusunan laporan kegiatan dan publikasi artikel yang diterbitkan dalam jurnal ilmiah, bertujuan untuk menambah referensi terkait penyuluha dan pendampingan masyarakat dalam menanggulangi dan menurunkan angka stunting.

\section{Hasil dan Pembahasan}

Salah satu upaya yang bisa dilakukan untuk mencegah dan menurunkan penderita stunting di Desa Sidodadi sebagai salah satu desa dengan penderita stunting terbanyak di Kecamatan Paiton Kabupaten Probolinggo yaitu melalui penyuluhan serta pendampingan cara merawat penderita stunting, menerapkan pola hidup sehat, pemenuhan gizi anak dan ibu hamil dengan model yang sederhana, murah dan praktis. Oleh karena itu, target luaran yang ingin dicapai dari kegiatan pengabdian kepada masyarakat ini dapat dilihat pada Tabel berikut. 
Tabel 2. Target dan luaran program pengabdian

\begin{tabular}{|c|c|}
\hline Target & Luaran \\
\hline $\begin{array}{l}\text { 1. Memberikan penyuluhan cara } \\
\text { merawat penderita stunting, pola } \\
\text { hidup sehat, pemenuhan gizi anak dan } \\
\text { ibu hamil kepada KPM PKH Desa } \\
\text { Sidodadi. }\end{array}$ & $\begin{array}{l}\text { 1. KPM PKH memiliki pengetahuan } \\
\text { dalam merawat penderita } \\
\text { stunting, penerapan pola hidup } \\
\text { sehat, pemenuhan gizi anak dan } \\
\text { ibu hamil dengan cara yang } \\
\text { sederhana, murah dan praktis. }\end{array}$ \\
\hline $\begin{array}{l}\text { 2. Melakukan pendampingan praktik } \\
\text { implementasi cara merawat penderita } \\
\text { stunting dan pencegahannya sesuai } \\
\text { materi penyuluhan yang sudah } \\
\text { diberikan dalam kehidupan sehari-hari. }\end{array}$ & $\begin{array}{l}\text { 2. KPM PKH mampu } \\
\text { mengimplementasikan cara } \\
\text { merawat penderita stunting dan } \\
\text { cara mencegahnya sejak dini } \\
\text { secara mudah, murah dan } \\
\text { praktis dalam kehidupan sehari- } \\
\text { hari. }\end{array}$ \\
\hline
\end{tabular}

Untuk menjalankan target berdasarkan luaran yang ingin dicapai, Tim pelaksanan PKM bersama mitra melaksanakan seluruh kegiatan berdasarkan tahapan-tahapan yang telah dirumuskan bersama, yaitu:

1. Menjalin Kerjasama Mitra dan Analisis Masalah

Dalam kegiatan ini, tim pelaksana PKM telah menjalin kerjasama dengan beberapa mitra yaitu Pendamping PKH, Polindes dan perangkat desa. Selain dilibatkan dalam proses pelaksanaan penyuluhan dan pendampingan, mitra kerjasama juga dilibatkan dalam mengkaji permasalahan, pemetaan sasaran peserta, penyusunan materi dan proses evaluasi.

Karena peserta yang menjadi sasaran kegiatan ini adalah anggota PKH, maka pendamping PKH sangat relevan dilibatkan dalam kegiatan PKM ini khususnya dalam melakukan pemetaan peserta serta memberikan masukan-masukan tentang model pendampingan yang sesuai. Dengan pengalaman pendampingan KPM PKH di Desa Sidodadi selama ini, pendamping PKH diharapkan dapat memberikan masukan dalam penentuan peserta kegiatan PKM sesuai kriteria, memberikan gambaran kondisi KPM PKH, serta memberikan masukan penentuan model pendampingan yang sesuai kondisi peserta.

Mitra lain yang dilibatkan dalam kegiatan PKM ini adalah pemerintah desa dan Polindes Desa Sidodadi. Dalam kerjasama ini aparatur desa dan 
Polindes penting dilibatkan dalam malakukan analisis masalah stunting di Desa Sidodadi, juga dilihatkan dalam penyusunan materi penyuluhan dan pendampingan sesuai dengan target yang ditetapkan. Kegiatan PKM ini dapat dijadikan sebagai stimulus bagi pemerintah dan Polindes Desa Sidodadi dalam mencegah dan menurunkan penderita stunting. Maka untuk menjamin program pencegahan stunting di Desa Sidodadi dapat dilakukan secara terus-menerus dan berkesinambungan, pemerintah desa dan Polindes dapat menyusun berbagai kebijakan dan program kegiatan lanjutan.

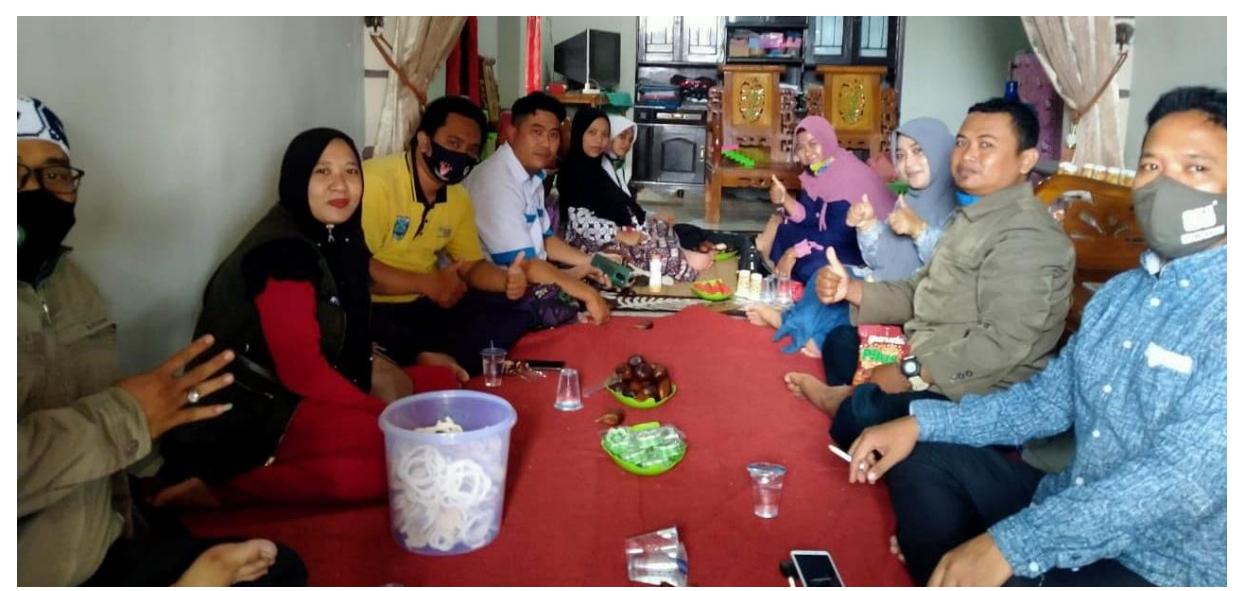

Gambar 2. Dokumentasi Diskusi Analisis Masalah Stunting

2. Menentukan Peserta dan Penyusunan Jadwal

Berdasarkan informasi yang diperoleh, jumlah KPM PKH Desa Sidodadi sebanyak 257 keluarga, dengan total ART yang memiliki kategori sebanyak 367 kategori meliputi kategori KPM kategori anak usia dini 48 orang, kategori SMA 101 orang, kategori SMP 84 orang, kategori SD 68 orang, kategori Bumil 0 orang, kategori Lansia 55 orang, dan kategori disabilitas 11 orang. 


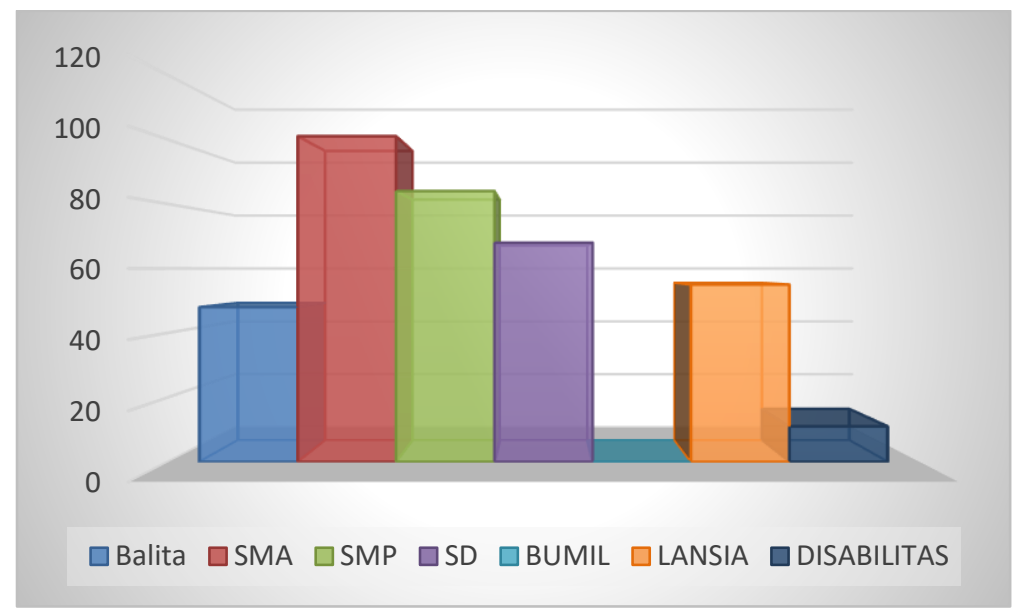

Gambar 3. Data KPM PKH Desa Sidodadi

Sesuai dengan target dan sasaran yang telah ditentukan, peserta kegiatan PKM ini adalah KPM PKH yang memiliki kategori lansia dan ibu hamil. Jumlah peserta ditentukan berdasarkan kapasitas tempat dan optimalisasi kegiatan yaitu sebanyak 30 peserta agar pelaksanaan penyuluhan dan pendampingan bisa lebih efektif dan efisien. Dari 30 peserta yang ikut selanjutnya bisa menjadi mentor bagi KPM PKH dan anggota masyarakat lain agar memiliki wawasan yang sama terkait penanganan stunting. Dengan demikian, program ini bisa berjalan secara berkelanjutan.

3. Merumuskan Materi dan Model Pendampingan

Penyusunan meteri penyuluhan dan pendampingan ini diawali dengan melakukan observasi terhadap kondisi masyarakat dan sampai di mana kemampuan yang sudah dimiliki. Dengan melakukan observasi langsung langsung, tim PKM dapat mengetahui permasalahan yang dihadapi. Langkah selanjutnya adalah menyusun rancangan materi sesingkat dan sejelas mungkin. Tujuannya agar materi yang disampaikan mudah dipahami dan dipraktekkan oleh peserta setelah pelatihan selesai.

Rancangan materi yang telah disusun oleh tim, kemudian disampaikan kepada mitra untuk dirumuskan bersama melalui diskusi dan jajak pendapat. Materi disusun berdasarkan permasalahan yang dihadapi, kondisi peserta, target yang ingin dicapai dan kebutuhan kegiatan. Dalam penyusunan materi ini masing-masing tim dan mitra diberi kebebasan untuk menyampaikan gagasan sesuai dengan pengalaman dan bidang 
masing-masing. Mitra Polindes menyampaikan berbagai fakta terkait kondisi stunting di Desa Sidodadi serta beberapa upaya yang telah dilakukan dalam palayanan dan penanganan stunting selama ini. Pendamping PKH menyampaikan konsep dan gagasan model penyuluhan dan pendampingan yang sesuai dengan kondisi peserta. Pemerintah desa menyampaikan rencana program tindak lanjut yang akan dilakukan pasca kegiatan PKM ini selesai.

Berbagai data dan masukan yang telah dihimpun dalam diskusi dan jajak pendapat dijadikan sebagai bahan dalam penyusunan materi penyuluhan dan model pendampingan. Beberapa pertimbangan dalam penyusunan materi kegiatan ini antara lain; Materi disusun sesuai dengan kebutuhan, sehingga dapat dirasakan langsung manfaatnya. Materi dibuat dengan bahasa yang mudah dimengerti, dan konten materi mudah untuk dipahami dan dipraktekkan. Materi disusun setepat mungkin berdasarkan hasil observasi dan masukan mitra, sehingga akan berdampak pada keefisienan waktu dan keefektifan pelatihan.

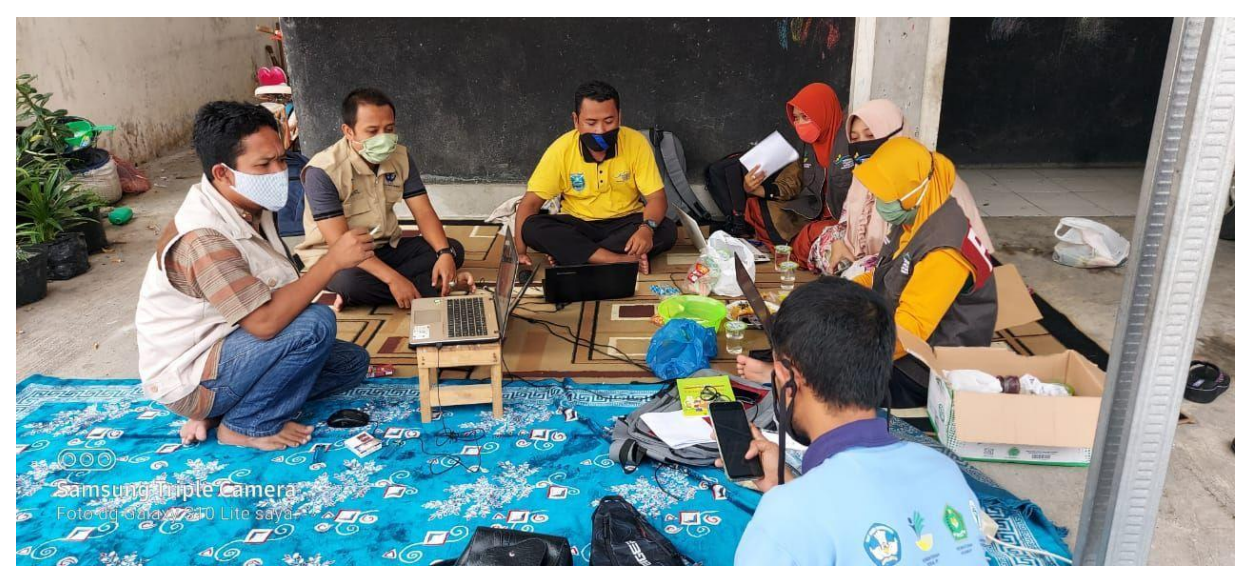

Gambar 4. Penyusunan Materi dan Model Pendampingan

Adapun materi yang diberikan dalam kegiatan penyuluhan penanganan dan pencegahan stunting ini adalah sebagai berikut:

1. Penyuluhan tentang cegah stunting sejak 1000 hari pertama kehidupan dan pemberian gizi seimbang balita. Materi ini diberikan dengan tujuan agar peserta memiliki pengetahuan dan mamou mengimplementasikan pentingnya mencegah stunting sejak 1000 hari pertama kehidupan dan dilanjutkan dengan gizi seimbang di usia balita. 
2. Penyuluhan tentang pentingnya pemeriksaan masa kehamilan. Materi ini diberikan untuk memberikan penyuluhan penyuluhan kesehatan tentang pentingnya pemeriksaan masa kehamilan untuk mengantisipasi dan mencegah stunting bayi saat lahir, sesuai dengan program pemerintah Indonesia dalam pencegahan stunting melalui program 1000 HPK. Salah satu upaya yang dilaksanakan dalam program 1000 HPK adalah memeberikan motivasi kepada ibu hamil agar melakukan pemeriksanaan secara rutin minimal empat kali pada masa kehamilan. Pemberian asupan gizi, makanan tambahan dan suplemen penambah darah.

3. Penyuluhan dan pemberian contoh menu seimbang dan Pemberian Makanan Tambahan (PMT) pada balita. Sesuai Peraturan Menteri Kesehatan Nomor 51 tahun 2016 dalam penanganan stunting adalah dengan memberikan makanan tambahan berbasis pangan lokal. Makanan lokal lebih mudah didapat dan dihasilkan secara mandiri oleh masing-masing keluarga dengan berbagai macam varian, namun ketersediaat zat gisi pangan lokal sangat ditentukan pada proses pengolahan/memasak. Oleh karena itu praktik dan pemberian contoh bagaimana mengolah makanan bergizi dari pangan lokal penting dilakukan.

Materi yang telah tersusun dan disepakati selanjutnya dijadikan acuan untuk merumuskan tahapan-tahapan dan model pendampingan. Model pendampingan didasarkan pada permasalahan, gagaan-gagasan, pemikiran-pemikiran, dan kecenderungan peserta. Pendampingan dilakukan untuk meningkatkan motivasi peserta agar aktif dan memiliki semangat tinggi dalam mencapai keberhasilan program menyesuaikan kondisi peserta. Selain itu pendampingan sekaligus dimanfaatkan mencari, menggali, dan mendayagunakan pengetahuan, keterampilan dan pengalaman untuk mengembangkan kemampuan peserta. Dengan berbagai keterampilan dan pengalamannya peserta dapat secara aktif melakukan eksperimentasi dan eksplorasi dalam usaha memecahkan semua masalah yang dihadapi. 


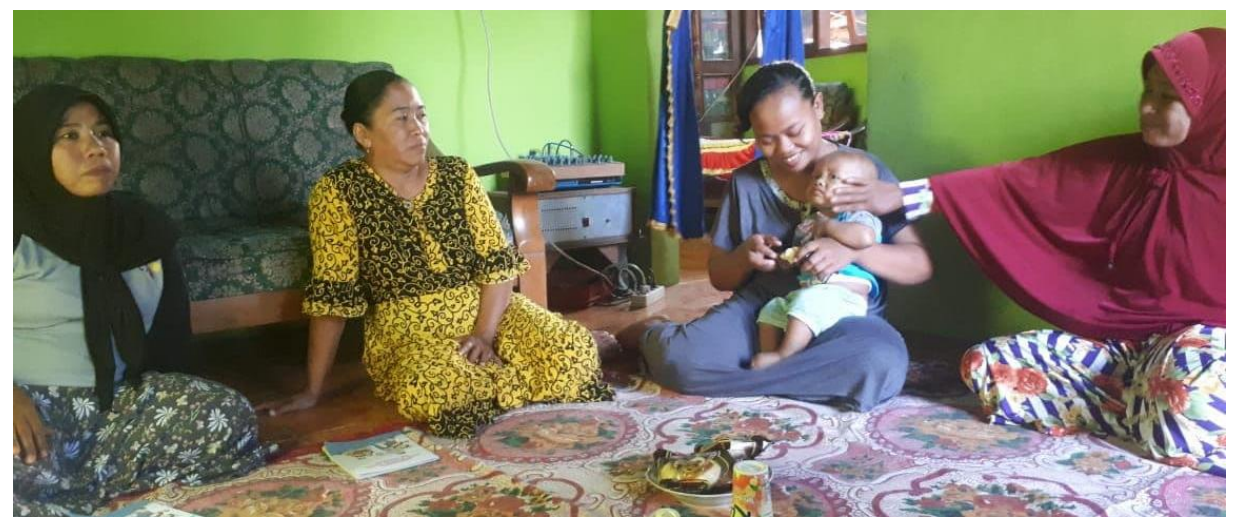

Gambar 5. Pendampingan Praktik Pencegahan dan Penanganan

Stunting

Adapun metode penyuluhan yang digunakan dalam kegiatan PKM ini meliputi:

1) Metode ceramah digunakan untuk menerangkan dan menjelaskan materi, pengertian atau pesan secara lisan kepada peserta sasaran sehingga memperoleh informasi tentang penanganan dan pencegahan stunting.

2) Metode diskusi kelompok diimplementasikan dalam bentuk pembicaraan yang direncanakan dan telah dipersiapkan tentang suatu topik masing-masing kelompok yang terdiri dari 5 peserta dengan seorang pemimpin diskusi yang telah ditunjuk. Selanjutnya masing-masing kelompok mempresentasikan hasil diskusinya kepada kelompok yang lain.

3) Metode curah pendapat diterapkan dalam bentuk pemecahan masalah di mana setiap peserta mengusulkan semua kemungkinan pemecahan masalah yang terpikirkan, dan evaluasi atas pendapatpendapat yang disampaikan.

4) Metode panel yaitu pembicaraan yang telah direncanakan di depan peserta tentang sebuah topik, diperlukan 3 orang atau lebih panelis dengan seorang pemimpin.

5) Metode bermain peran diterapkan dengan cara peserta memerankan sebuah situasi dalam kehidupan manusia dengan tanpa diadakan latihan, dilakukan oleh dua orang atu lebih untuk dipakai sebagai bahan pemikiran oleh kelompok.

6) Metode demonstrasi dilakukan dengan cara menunjukkan pengertian, ide dan prosedur tentang penanganan dan pencegahan stunting yang telah dipersiapkan dengan teliti untuk memperlihatkan bagaimana cara melaksanakan suatu tindakan, adegan dengan menggunakan alat peraga. 
7) Metode simposium yaitu serangkaian ceramah yang diberikan oleh 2 sampai 3 orang peserta dengan topik yang berlebihan tetapi saling berhubungan erat.

8) Metode seminar diterapkan dengan cara sekelompok peserta yang terdiri dari 4-5 orang berkumpul untuk membahas suatu masalah dibawah bimbingan pendamping yang menguasai bidangnya.

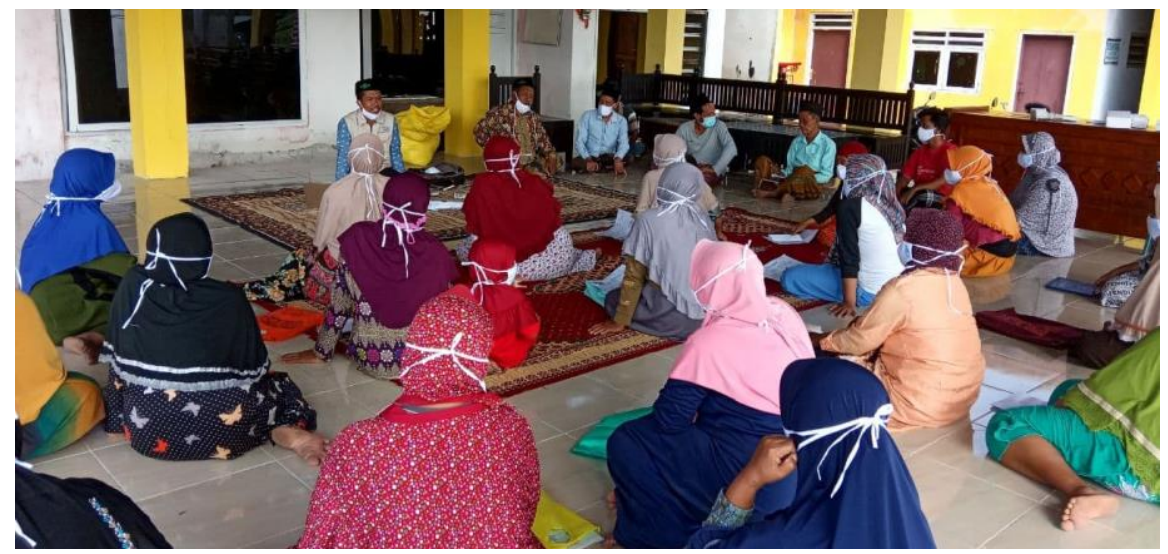

Gambar 5. Penyuluhan penanganan dan pencegahan stunting

4. Pengukuran Hasil dan Evaluasi

Pengukuran hasil kegiatan PKM ini adalah peningkatan pengetahuan dan sikap KPM PKH sebagai sasaran program penanganan dan pencegahan stunting di Desa Sidodadi Kecamatan Paiton Kabupaten Probolinggo. Cara pengukuran dilakukan dengan memberikan kuesioner pre-test dan post-test kegiatan. Pre-test diberikan pada minggu pertama dan post-test diberikan pada minggu ke-empat. Adapun pengukuran hasil kegiatan PKM ini sebagai berikut:

Tabel 3. Pengukuran hasil PKM

\begin{tabular}{|c|c|c|c|c|c|}
\hline \multirow{2}{*}{$\begin{array}{c}\text { Pengetahuan } \\
\text { dan Sikap }\end{array}$} & \multicolumn{2}{|c|}{ Sebelum Kegiatan } & \multicolumn{2}{|c|}{ Sesudah Kegiatan } & \multirow{2}{*}{ P Value } \\
\hline & $\mathrm{F}$ & $\%$ & $\mathrm{~F}$ & $\%$ & \\
\hline Pengetahuan & & & & & 0,608 \\
\hline Kurang & 18 & $60 \%$ & 6 & $20 \%$ & \\
\hline Baik & 10 & $33 \%$ & 8 & $27 \%$ & \\
\hline Sangat Baik & 2 & $7 \%$ & 16 & $53 \%$ & \\
\hline Sikap & & & & & 0,001 \\
\hline Baik & 23 & $77 \%$ & 19 & $63 \%$ & \\
\hline Sangat Baik & 7 & $23 \%$ & 11 & $37 \%$ & \\
\hline
\end{tabular}


Sebagaimana terlihat dalam tabel di atas, hasil ini terlihat bahwa pengetahuan peserta mengalami peningkatan yang sangat segnifikan sebelum dan setelah kegiatan penyuluhan dan pendampingan, begitu juga peningkatan sikap peserta yang sangat signifikan dalam penanganan dan pencegahan stunting. Namun, sebanyak 6 peserta masih memiliki tingkat pegetahuan kurang. Pengetahuan peserta terkait pencegahan dan penanganan stunting memberikan efek yang signifikan terhadap keakuratan dan ketidakakuratan paparan informasi yang mereka dapatkan.

Untuk mengindentifikasi pemasalahan serta kendala yang muncul dalam kegiatan PKM ini, maka tim bersama mitra melakukan kegiatan evaluasi. Hasil evaluasi ini selanjutnya akan dijadikan sebagai acuan dalam menyusun rencana tindak lanjut program.

\section{Kesimpulan}

Kagiatan PKM ini dilakukan dengan 2 model yaitu pemberian penyuluhan dan pendampingan praktik. Secara umum kegiatan PKM berjalan dengan baik dan lancar sesuai tahapan-tahapan dan terget yang telah ditentukan. Jika dilihat dari pengukuran hasil pre-tes dan post-test, kegiatan ini telah berhasil mencapai target dengan meningkatnya pengetahuan peserta tentang penanganan dan pencegahan stunting. Dimana dari hasil pre-test dengan tingkat pengetahuan baik sekali berjumlah $7 \%$, tingkat pengetahuan baik 33\% dan tingkat pengetahuan kurang $60 \%$ mengalami peningkatan pengetahuan sesuai hasil post-test dengan jumlah prosentase peserta yang tingkat pengetahuan baik sekali mencapai 53\%, tingkat pengetahuan baik $27 \%$ dan tingkat pengetahuan kurang menurun menjadi $20 \%$.

Setelah kegiatan PKM ini diharapkan KPM PKM yang telah mengikuti kegiatan ini mampu berperan menjadi pendamping dan mentor masyarakat lain agar memiliki pengetahuan yang sama dalam melakukan penanganan dan pencegahan stunting di Desa Sidodadi Kecamatan Paiton Kabupaten Probolinggo. 


\section{Pengakuan}

Tim KKN PKM mengucapkan terimakasih banyak atas kerjasamanya kepada seluruh pemerintah Desa Sidodadi dan Petugas Polindes Desa Sidodadi, Pendamping PKH Kecamatan Paiton, selaku mitra pada pelaksanaan PKM ini. Terima juga disampaikan kepada seluruh pengurus LP3M Universitas Nurul Jadid yang telah memberi amanah kepada tim PKM untuk melaksanakan kegiatan penyuluhan dan pendampingan penanganan dan pencegahan stunting kepada KPM PKH Desa Sidodadi Kecamatan Paiton Kabupaten Probolinggo.

\section{Referensi}

Aryu Candra, (2020). Epistimologi Stunting, Fakultas Kedokteran Universitas Diponegoro, Semarang.

Bappenas. (2018). Pedoman pelaksanaan intervensi penurunan stunting terintegrasi di kabupaten/Kota, Deputi Bidang Pembangunan Manusia, Masyarakat dan Kebudayaan Kementerian Perencanaan Pembangunan Nasional/Bappenas, Jakarta

Hasto Wardoyo. (2016). Bela Beli Kulon Progo. Yogyakarta: Pusat Studi Kebijakan Daerah.

https://aksi.bangda.kemendagri.go.id/emonev/DashPrev

Kemenkes RI, (2018). Bersama Cagah Stunting, Warta Kesmas Edisi 02, Jakarta.

Khadijah. (2016). Perkembangan Kognitif Anak Usia Dini. Perdana Publishing, Medan.

Ramayulis, R. dkk. (2018). Stop Stunting dengan Konseling Gizi, Swadaya Group. Jakarta.

Sartono (2014) 'Hubungan kurang energi kronis ibu hamil dengan kejadian stunting pada anak usia 6-24 bulan di Kota Yogyakarta'. 